\title{
Integrated Management for the Reduction of Calonectria Infections in Ornamental Nurseries
}

Alessandro Cinquerrui, Giancarlo Polizzi, Dalia Aiello, and Alessandro Vitale, Dipartimento di Agricoltura, Alimentazione e Ambiente, University of Catania, Via S. Sofia 100, 95123 Catania, Italy

\begin{abstract}
Chemical control represents the main effective strategy for managing Calonectria diseases in ornamental nurseries. The occurrence of fungicideresistant strains and the European Directive on "Sustainable Use of Pesticides" has forced ornamental plant growers to establish effective integrated pest management strategies to control Calonectria infections. Here, three nursery experiments were performed to detect the best combinations of fungicides and biological control agents (BCA) to control both leaf spot, caused by six Calonectria spp. on bottlebrush and metrosideros, and stem rot, caused by Calonectria morganii on Dodonaea plants. Overall, the cyprodinil + fludioxonil mixture alone or combined with bioformulates containing Bacillus, Trichoderma, and Streptomyces spp. provided the best performance in reducing leaf spot and stem rot

caused by Calonectria spp., followed by the mixture of boscalid + pyraclostrobin. Although BCA alone provided disease suppression significantly lower than the controls in most cases, these treatments were, on average, the least effective in controlling Calonectria infections. Otherwise, there were no significant increases in efficacy with fungicides plus BCA over fungicides alone. Thus, the application of boscalid + pyraclostrobin and cyprodinil + fludioxonil mixtures may also be used in largescale applications to reduce Calonectria diseases because they effectively managed leaf and stem infections. Our comprehensive research applied previously acquired information on Calonectria disease management in nurseries, resulting in important data that affects integrated plans to fight these pathogens in accordance with European legislation.
\end{abstract}

In the last decade, the ornamental industry has increased its production levels worldwide (Daughtrey and Benson 2005). Because of climatic conditions, the Mediterranean basin plays an important role in the production of ornamental plants in Europe. However, producing healthy and marketable plants can be difficult, and unfavorable agronomic and phytosanitary conditions can limit plant production under nursery, field, and greenhouse conditions.

Of the phytopathological issues, diseases caused by Calonectria spp. such as Calonectria pauciramosa, C. morganii, C. polizzii, C. mexicana, C. pseudomexicana, and C. tunisiana are the most widespread in the Mediterranean basin, affecting many economically important crops. These plant pathogens are responsible for several different symptoms, including crown and root rot, stem rot, leaf spotting, and shoot blight, in ornamental plants (Crous 2002; Henricot and Beales 2003; Lombard et al. 2011; Pérez-Sierra et al. 2007; Polizzi and Catara 2001; Polizzi and Crous 1999; Polizzi et al. 2006, 2009; Vitale and Polizzi 2008; Vitale et al. 2013b). Consequently, adequate control strategies focused on chemical and physical measures are needed to manage Calonectria infections in nurseries (Vitale et al. 2013a,b). The application of fungicides is the most used approach to reduce economic losses, and many fungicides, belonging to different chemical classes, have been used to control Calonectria diseases (Aiello et al. 2013). Preventive applications of methyl benzimidazole carbamates (MBC: thiophanate-methyl) and demethylation inhibitors (DMI: prochloraz) reduce Calonectria infections (Aiello et al. 2013; Barnard 1984; Bertus 1976; Chase 1987; Crous 2002; Engelhard 1971; Horst and Hoitink 1968; Roos 1980, 1981).

Recently, thiophanate-methyl, fludioxonil, pyraclostrobin, trifloxystrobin, kresoxim-methyl, mancozeb, and chlorothalonil were demonstrated to reduce mycelial growth and conidial germination of C. pseudonaviculata under in vitro conditions (LaMondia 2014).

Although the application of fungicides such as MBC and DMI is effective in controlling Calonectria diseases, their prolonged use has led to the selection of fungicide-resistant strains (Alfenas et al.

Corresponding author: A. Vitale; E-mail: alevital@unict.it

Accepted for publication 29 August 2016.

C) 2017 The American Phytopathological Society
1988; Guarnaccia et al. 2014; Vitale et al. 2009). According to the latest European Directive 2009/128/EC on the "Sustainable Use of Pesticides", modern agriculture is currently focused on biological control agent (BCA) use and on reducing fungicide applications. Environmentally friendly approaches to controlling plant diseases are being legislated. After January 2014, each member country of the European Economic Community was encouraged to adopt an integrated pest management (IPM) strategy by establishing a National Action Plan (Hillocks 2012). Directive 91/414/EEC stated that "the use of plant protection products is limited to the strict minimum necessary to maintain the pest population below the economic damage threshold", which does not mean that pesticides cannot be used but that they should be used in combination with alternative measures that reduce the required amounts of chemical compounds (Hillocks 2012). This concept is emphasized by the European Crop Protection Association, which confirms that the use of pesticides in an IPM program is not facultative because their use should ensure that the IPM programs are more economically and medically beneficial than just chemical or biological treatments (Hillocks 2012). Establishing sanitation and monitoring measures is essential to prevent plant disease development and, consequently, to obtain a satisfactory production level under a qualitative profile. However, it is equally significant to determine integrated control measures for the management of diseases found in greenhouses and nurseries (Daughtrey and Benson 2005).

Thus, this article aimed to evaluate combinations of BCA and fungicides to manage Calonectria infections on important ornamental hosts, thereby reducing the economic losses in ornamental nurseries in the Mediterranean basin.

\section{Materials and Methods}

Fungal isolates. Six Calonectria spp. were used in this study: C. mexicana (CBS130353 from Dodonaea viscosa), C. morganii (CBS120930 from Callistemon hybrid 'Rose Opal'), Calonectria pauciramosa (CBS130333 from Callistemon citrinus (Curtis) Skeels), Calonectria polizzii (CBS130351 from Myrtus communis), C. pseudomexicana (CBS 130354 from Callistemon sp.), and C. tunisiana (CBS130357 from Callistemon laevis An.) (Crous 2002; Lombard et al. 2010, 2011; Polizzi and Crous 1999).

A fresh culture of each isolate was obtained by transferring agar plugs from stock cultures onto potato dextrose agar (PDA; Oxoid, Basingstoke, UK) plates. Subsequently, 5-mm mycelial plugs, taken 
from the edge of a 5-day-old colony grown on PDA, were placed onto synthetic low-nutrient agar dishes and incubated at $25^{\circ} \mathrm{C}$ for 21 days. A conidial suspension was prepared by adding sterile distilled water to the dishes, gently rubbing the colony surface with a sterile loop, and then filtering the solution through three layers of cheesecloth. A final spore suspension of approximately $2.5 \times 10^{5}$ conidia $\mathrm{ml}^{-1}$ was determined using a hemocytometer.

BCA and fungicides. Three experiments were performed in three greenhouses, at the geographical coordinates $37^{\circ} 41^{\prime} 50.54^{\prime \prime} \mathrm{N}$, $15^{\circ} 11^{\prime} 37.45^{\prime \prime} \mathrm{E}$; $37^{\circ} 41^{\prime} 50.01 \mathrm{~N}, 1^{\circ} 11^{\prime} 37.47^{\prime \prime} \mathrm{E}$; and $37^{\circ} 41^{\prime} 55.80^{\prime \prime}, \mathrm{N}$ $15^{\circ} 11^{\prime} 38.61^{\prime \prime} \mathrm{E}$, respectively, within a nursery located in Carruba, Riposto, Catania Province, Italy. In experiments I and III, the efficacies of BCA and fungicides, applied alone or in combinations, in controlling leaf spots caused by different Calonectria spp. on Callistemon spp. and Metrosideros spp. were assayed, while, in experiment II, the abilities of these treatments to control stem rot caused by $\mathrm{Cal}$ onectria morganii on D. viscosa were tested.

Experiment I. Efficacy of chemical and biological treatments in controlling Calonectria leaf spot caused by $C$. morganii on Callistemon viminalis. In this experiment, the capabilities of four commercial fungicides and seven microbiological formulates to control leaf spots caused by inoculations of Calonectria morganii on Callistemon viminalis were tested (Table 1). Each treatment was replicated three times in a randomized complete block design (RCBD) with 32 to 42 bottlebrush cuttings. The same number of untreated inoculated bottlebrush cuttings served as positive controls. In this experiment, BCA and fungicides were applied 24 and $3 \mathrm{~h}$, respectively, before pathogen inoculation. Each treatment was performed by spraying approximately $30 \mathrm{ml}$ of suspension for each replicate to run-off using a hand pump. The $C$. morganii inoculum of approximately $30 \mathrm{ml}$ of conidial suspension (approximately $2.5 \times 10^{5}$ $\mathrm{CFU}$ ) for each replicate was sprayed on the leaf surface of the bottlebrush using a hand-pump. After inoculation, bottlebrush cuttings were covered with plastic tunnels for 3 days and then maintained in a greenhouse at a temperature of approximately $25^{\circ} \mathrm{C}$. The capabilities of the fungicides and BCA to control leaf spot symptoms were evaluated 10 days after inoculation by calculating the disease incidence of infected plants $\left(\mathrm{DI}_{\mathrm{P}}\right)$, disease incidence of infected leaves $\left(\mathrm{DI}_{\mathrm{L}}\right)$, and symptom severity (SS). Both DI values were calculated as percentages of cuttings or leaves showing symptoms out of the total number of plants or leaves examined $\times 100$. However, the SS value was determined by using an empirical 1-to-5 rating scale based on the percentage of the foliar surface infected, as follows: $1=$ healthy cuttings and $2=1$ to $5,3=6$ to $25,4=26$ to 50 , and $5=$ more than $50 \%$ of leaf area infected. Both the average $\mathrm{DI}_{\mathrm{L}}$ and SS values were based on 10 leaves/cutting. SS values were converted to mean disease ratings calculated as $\Sigma$ (the number of diseased leaves for each single class $\times$ the disease class)/number of leaves scored. This experiment was repeated twice.

Experiment II. Efficacies of chemical, biological and integrated treatments in controlling $C$. morganii on $D$. viscosa. Different treatments consisting of chemical, biological, or combined control means were tested in this nursery experiment for their capabilities to inhibit Calonectria stem rot caused by $C$. morganii on $D$. viscosa. The scheduled spray program included 17 different treatments consisting of both tested active ingredients, which had already been reported as effective against Calonectria infections in nurseries (Aiello et al. 2013; Henricot and Wedgwood 2013; Henricot et al. 2008; LaMondia 2015; Vitale et al. 2012), and untested active ingredients. Thus, six commercial fungicides (including one containing the active ingredient etridiazole, active against oomycetes and also Fusarium spp.) and five microbiological formulates were used alone or in combination following the application rates recommended by their manufacturers (Table 1).

Treatments were arranged in an RCBD with three replications, each containing $28 \mathrm{D}$. viscosa seedlings. The same number of untreated inoculated seedlings served as positive controls. This experiment was performed twice.

For each trial, BCA were applied both 21 and 3 days before pathogen inoculation, whereas fungicides were applied 1 day before pathogen inoculation. The crown area of each $D$. viscosa seedling was inoculated with approximately $0.5 \mathrm{ml}$ of conidial suspension (approximately $2.5 \times 10^{5} \mathrm{CFU}$ ) of $C$. morganii as a soil drench. Then, inoculated young seedlings were covered for 3 days under plastic tunnels and maintained at $25 \pm 2{ }^{\circ} \mathrm{C}$. Biological and chemical treatments were repeated 6 and 8 days after inoculation, respectively. The application mode for the commercial formulations was the same as in the previous experiment.

Twenty-one days after pathogen inoculation, DI and SS were recorded. The former was calculated as the percentages of the number of symptomatic plants out of the total number of plants examined $x$ 100 . The SS value was calculated by measuring the length (in centimeters) of necrotic stem tissue.

Experiment III. Fungicide and BCA efficacies in controlling Calonectria leaf spot on Metrosideros excelsa 'Aurea' and Callistemon 'Captain Cook' in a nursery. The efficacies of three fungicides and three microbiological formulations, applied alone or in combinations, were tested against five species of the genus Calonectria (C. pauciramosa, C. polizzii, C. pseudomexicana, C. tunisiana, and C. mexicana) on both Metrosideros excelsa 'Aurea' and Callistemon 'Captain Cook'. The fungicides boscalid + pyraclostrobin (Signum), cyprodinil + fludioxonil (Switch), and fosetyl-Al (Aliette), and the microbiological formulates Bacillus amyloliquefaciens subsp. plantarum D747 (Amylo-X), B. subtilis QST713 (Serenade

Table 1. Fungicides and biological control agents employed in the experiments (Exp)

\begin{tabular}{|c|c|c|c|c|c|}
\hline Active ingredient & Trade name & Manufacturer & Rates (g or ml/100 liters) & Formulation $(\%)^{\mathrm{z}}$ & Exp \\
\hline $\begin{array}{l}\text { Bacillus amyloliquefaciens subsp. } \\
\text { plantarum D747 }\end{array}$ & Amilo-X & Biogard & 250 & $25 \mathrm{WG}$ & I, II, III \\
\hline B. subtilis QST713 & Serenade Max & Bayer Crop Science & 400 & $15.67 \mathrm{WP}$ & I, II, III \\
\hline Boscalid + pyraclostrobin & Signum & Basf Italia & 100 & $26.7+6.7 \mathrm{WG}$ & I, II, III \\
\hline Cyprodinil + fludioxonil & Switch & Syngenta Crop Protection & 80 & $37.5+25 \mathrm{WG}$ & II, III \\
\hline Etridiazole & Terrazole & Certis Europe & 400 & $25 \mathrm{EC}$ & II \\
\hline Fludioxonil & Geoxe & Syngenta Crop Protection & 50 & $50 \mathrm{WG}$ & II \\
\hline Fluopyram & Luna Privilege & Bayer Crop Science & 50 & $41.66 \mathrm{SC}$ & I \\
\hline Fosetyl-Al & Aliette & Bayer Crop Science & 300 & $80 \mathrm{WG}$ & I, II, III \\
\hline Propamocarb + fosetyl-Al & Previcur Energy & Bayer Crop Science & 250 & $47.2+27.6 \mathrm{SL}$ & I \\
\hline Streptomyces griseoviridis $\mathrm{K} 61$ & Mycostop & Bioplanet & 25 & $33.33 \mathrm{WP}$ & I, II \\
\hline Thiophanate-methyl & Ranger Gold & Diachem & 100 & $38.3 \mathrm{SC}$ & II \\
\hline Trichoderma asperellum TV1 & Xedavir & Xeda Italia & 400 & $2.8 \mathrm{WP}$ & I \\
\hline T. atroviride $\mathrm{T} 11+T$. asperellum $\mathrm{T} 25$ & Tusal & Certis Europe & 250 & $0.5+0.5 \mathrm{WG}$ & I, II, III \\
\hline T. harzianum ICC012 + T. viride ICC080 & Radix & Certis Europe & 250 & $2+2 \mathrm{WP}$ & I \\
\hline T. harzianum $\mathrm{T} 22$ & Trianum-P & Koppert Italia & 100 & $1.15 \mathrm{WP}$ & I, II \\
\hline
\end{tabular}

${ }^{\mathrm{z}}$ Percentage of active ingredient. $\mathrm{WG}=$ water-dispersible granule, $\mathrm{WP}=$ wettable powder, $\mathrm{SL}=$ soluble concentration, $\mathrm{SC}=$ suspended concentration, and $\mathrm{EC}=$ emulsifiable concentration. 
Max), and Trichoderma atroviride $\mathrm{T} 11+T$. asperellum T25 (Tusal) were employed as commercial products at the recommended application rates (Table 1).

Each treatment was replicated three times in an RCBD using 28 metrosideros and 3 bottlebrush cuttings per replicate. The same number of untreated inoculated cuttings served as positive controls.

The application modes and times for BCA and fungicides were as in experiment I. Each Calonectria sp. inoculum consisted of a spray volume of approximately $25 \mathrm{ml}$ for metrosideros and approximately $10 \mathrm{ml}$ for bottlebrush of a conidial suspension (approximately $2.5 \times$ $10^{5} \mathrm{CFU}$ ) for each replicate. After inoculation, plants were maintained under plastic tunnels at $25 \pm 2{ }^{\circ} \mathrm{C}$ and approximately $70 \%$ relative humidity for 3 days.

Disease evaluation was performed as in experiment I, including adopting the same scale for SS. However, SS values were averaged using 5 and 15 leaves/plant for metrosideros and bottlebrush, respectively, and only reported to compare the fungicide efficacies across pathogens.

Statistical analysis. All of the data obtained from the in vivo experiments were subjected to an analysis of variance using the statistical package Statsoft (version 10; Statsoft Inc., Tulsa, OK) according to a parametric approach, with the factorial treatment structure and interactions with treatments arranged in an RCBD with three replicates. Because a significant effect was detected in each experiment for all of the interactions from the repeated trials, they were analyzed separately. All of the DI percentage data were transformed using arcsine $\left(\sin ^{-1} \times\right.$ square root $\left.x\right)$ prior to statistical analysis.

In the posthoc analyses, the mean values of DI and SS of Calonectria sp. infections were subsequently separated by the NewmanKeuls test $(\alpha=0.05)$.

\section{Results}

Experiment I. Fungicide and BCA efficacies in controlling $C$. morganii on $C$. viminalis in the nursery. In all of the nursery trials, some of the treatments had significant effects $(P<0.001)$ on $\mathrm{Cal}$ onectria infections. Because significant treatment-trial interactions were also detected for the mean $\mathrm{DI}_{\mathrm{P}}, \mathrm{DI}_{\mathrm{L}}$, and $\mathrm{SS}$ values, individual trial results are presented in Table 2 . The disease pressure was very high in the first and third trials, whereas a lower disease level was recorded in the second trial.

In all of the trials, boscalid + pyraclostrobin, fluopyram, and B. subtilis QST713 were the most effective treatments in controlling Calonectria leaf spot on $C$. viminalis. Under high disease pressure, these treatments showed the best performances, being significantly different than most of the other treatments. Under low disease levels, boscalid + pyraclostrobin, fluopyram, and B. subtilis QST713 were the only treatments that were significantly different from their relative controls and most of the remaining treatments.

The least effective treatments were $T$. atroviride $\mathrm{T} 11+T$. asperellum $\mathrm{T} 25, T$. harzianum ICC012 + T. viride ICC080, T. asperellum TV1, and T. harzianum T22, and Streptomyces griseoviridis K61 (Table 2).

Experiment II. Efficacies of chemical, biological, and integrated treatments in controlling $C$. morganii on $D$. viscosa. Because the treatment-trial interactions were significant $(P=0.0023)$, data for each trial are shown separately in Table 3. In both trials, some treatments had significant effects on reducing stem rot infections caused by $C$. morganii, and their performances were evaluated based on the simultaneous analyses of the disease variables. In the two nursery trials, the DI values of the untreated infected plants ranged from 53.6 to $81 \%$, while the SS values ranged from 0.81 to $1.26 \mathrm{~cm}$. All of the fungicides and BCA, applied individually or in combination, had significant control effects on the stem rot of $D$. viscosa caused by $C$. morganii.

In the first trial, the cyprodinil + fludioxonil fungicide mixture applied alone or in combination with applications of bioformulation containing Trichoderma spp. and Streptomyces strains, showed the best performances in controlling both the DI and the SS of stem rot, with values of 2.4 to $6 \%$ and 0.02 to $0.06 \mathrm{~cm}$, respectively. A reduction in disease was also observed for the remaining combinations of the above fungicide mixture with the remaining BCA and for thiophanate-methyl. T. harzianum $\mathrm{T} 22$, followed by etridiazole, were the least effective treatments in reducing infections caused by C. morganii, with values of 36.9 and $39.3 \%$ for DI, respectively, and 0.37 and $0.60 \mathrm{~cm}$ for SS, respectively (Table 3). An intermediate efficacy in reducing $C$. morganii infections on Dodonaea seedlings was detected for the remaining fungicide and BCA applications. The results of the second trial confirmed those obtained in the first, with very slight differences (Table 3 ). The cyprodinil + fludioxonil fungicide mixture applied alone or in combination with the tested BCA once again had the highest efficacies in reducing $C$. morganii infections on Dodonaea seedlings. Etridiazole showed the worst efficacy against the fungal pathogen, whereas thiophanate-methyl and boscalid + pyraclostrobin revealed a certain efficacy in controlling Dodonaea stem rot. All of the remaining treatments showed an intermediate capability to reduce $C$. morganii infections on Dodonaea seedlings.

Experiment III. Fungicide and BCA efficacies in controlling Calonectria leaf spot on M. excelsa Aurea and Callistemon Captain Cook in a nursery. In these nursery experiments, in which both M. excelsa Aurea and Callistemon Captain Cook were independently inoculated with C. mexicana, C. pauciramosa, C. polizzii, C. pseudomexicana, and $C$. tunisiana, some treatments (fungicide and BCA treatments alone or combined) showed significant effects on Calonectria sp. infections $(\alpha=0.05)$. Because the treatment-pathogen-host

Table 2. Effects of fungicides and biological control agents against leaf spot caused by Calonectria morganii on bottlebrush (Callistemon viminalis) in experiment $\mathrm{I}^{\mathrm{Z}}$

\begin{tabular}{|c|c|c|c|c|c|c|c|c|c|}
\hline \multirow[b]{2}{*}{ Treatment } & \multicolumn{3}{|c|}{ First trial } & \multicolumn{3}{|c|}{ Second trial } & \multicolumn{3}{|c|}{ Third trial } \\
\hline & $\mathbf{D I}_{\mathbf{P}}$ & $\mathbf{D I}_{\mathbf{L}}$ & SS & $\mathbf{D I}_{\mathbf{P}}$ & $\mathbf{D I}_{\mathbf{L}}$ & SS & $\mathbf{D I}_{\mathbf{P}}$ & $\mathbf{D I}_{\mathbf{L}}$ & SS \\
\hline Boscalid + pyraclostrobin & $2.3 \mathrm{c}$ & $0.2 \mathrm{c}$ & $1.00 \mathrm{c}$ & $1.6 \mathrm{c}$ & $0.4 \mathrm{c}$ & $1.00 \mathrm{c}$ & $0.0 \mathrm{e}$ & $0.0 \mathrm{~d}$ & $1.00 \mathrm{~b}$ \\
\hline Fluopyram & $4.6 \mathrm{c}$ & $1.1 \mathrm{c}$ & $1.01 \mathrm{bc}$ & $0.0 \mathrm{c}$ & $0.0 \mathrm{c}$ & $1.00 \mathrm{c}$ & $1.3 \mathrm{de}$ & $0.1 \mathrm{~cd}$ & $1.00 \mathrm{~b}$ \\
\hline Bacillus subtilis QST713 & $10.5 \mathrm{c}$ & $1.8 \mathrm{c}$ & $1.07 \mathrm{bcd}$ & $1.6 \mathrm{c}$ & $0.2 \mathrm{c}$ & $1.00 \mathrm{c}$ & $1.3 \mathrm{de}$ & $0.1 \mathrm{~cd}$ & $1.00 \mathrm{~b}$ \\
\hline B. amyloliquefaciens subsp. plantarum D747 & $19.7 \mathrm{bc}$ & $2.7 \mathrm{c}$ & $1.03 \mathrm{bc}$ & $4.8 \mathrm{bc}$ & $1.4 \mathrm{bc}$ & $1.02 \mathrm{c}$ & $10.7 \mathrm{bcd}$ & $1.5 \mathrm{bc}$ & $1.01 \mathrm{~b}$ \\
\hline Fosetyl-Al & $17.2 \mathrm{bc}$ & $4.1 \mathrm{c}$ & $1.05 \mathrm{bcd}$ & $22.2 \mathrm{ab}$ & $11.3 \mathrm{a}$ & $1.21 \mathrm{a}$ & 5.3 cde & $1.3 \mathrm{bcd}$ & $1.02 \mathrm{~b}$ \\
\hline Propamocarb + fosetyl-Al & $16.0 \mathrm{bc}$ & $5.0 \mathrm{bc}$ & $1.06 \mathrm{bcd}$ & $18.2 \mathrm{ab}$ & $7.0 \mathrm{ab}$ & $1.11 \mathrm{bc}$ & $25.3 \mathrm{~b}$ & $4.5 \mathrm{~b}$ & $1.05 \mathrm{~b}$ \\
\hline $\begin{array}{l}\text { Trichoderma atroviride } \mathrm{T} 11+T \text {. asperellum } \\
\text { T25 }\end{array}$ & $46.6 \mathrm{ab}$ & $15.0 \mathrm{ab}$ & $1.19 \mathrm{abc}$ & $14.3 \mathrm{ab}$ & $7.6 \mathrm{ab}$ & $1.11 \mathrm{bc}$ & $13.3 \mathrm{bcd}$ & $2.7 \mathrm{~b}$ & $1.04 \mathrm{~b}$ \\
\hline T. harzianum ICC012 + T. viride ICC080 & $51.4 \mathrm{ab}$ & $15.8 \mathrm{ab}$ & $1.19 \mathrm{abc}$ & $18.2 \mathrm{ab}$ & $6.9 \mathrm{ab}$ & $1.13 \mathrm{~b}$ & $20.0 \mathrm{bc}$ & $3.9 \mathrm{~b}$ & $1.04 \mathrm{~b}$ \\
\hline T. asperellum TV1 & $60.8 \mathrm{a}$ & $20.4 \mathrm{a}$ & $1.26 \mathrm{a}$ & $5.6 \mathrm{bc}$ & $1.8 \mathrm{bc}$ & $1.03 \mathrm{bc}$ & $12.0 \mathrm{bcd}$ & $2.3 \mathrm{~b}$ & $1.02 \mathrm{~b}$ \\
\hline Streptomyces griseoviridis $\mathrm{K} 61$ & $69.1 \mathrm{a}$ & $16.9 \mathrm{ab}$ & $1.22 \mathrm{ab}$ & $11.9 \mathrm{ab}$ & $5.3 \mathrm{ab}$ & $1.05 \mathrm{bc}$ & $13.3 \mathrm{bcd}$ & $2.7 \mathrm{~b}$ & $1.03 \mathrm{~b}$ \\
\hline T. harzianum $\mathrm{T} 22$ & $64.4 \mathrm{a}$ & $15.5 \mathrm{ab}$ & $1.18 \mathrm{abcd}$ & $26.2 \mathrm{ab}$ & $13.4 \mathrm{a}$ & $1.22 \mathrm{a}$ & $20.0 \mathrm{bc}$ & $4.5 \mathrm{~b}$ & $1.07 \mathrm{~b}$ \\
\hline Untreated and inoculated control & $83.3 \mathrm{a}$ & 23.9 a & $1.30 \mathrm{a}$ & $34.1 \mathrm{a}$ & $13.7 \mathrm{a}$ & $1.25 \mathrm{a}$ & $78.7 \mathrm{a}$ & $16.9 \mathrm{a}$ & $1.21 \mathrm{a}$ \\
\hline
\end{tabular}

${ }^{\mathrm{z}}$ Data are the means of three replicates, each containing 32 to 42 bottlebrush cuttings. Values followed by the same letters within a column are not significantly different according to the Newman-Keuls test $(\alpha=0.05)$ for disease incidence of infected plants $\left(\% ; \mathrm{DI}_{\mathrm{P}}\right)$, disease incidence of infected leaves $\left(\% ; \mathrm{DI}_{\mathrm{L}}\right)$, and $\mathrm{SS}=$ symptom severity (centimeters; SS). Arcsine square root transformation was applied on percentage values prior to data analysis. 
and treatment-host interactions were always significant, the data on treatment efficacies are presented independently for each Calonectria sp. (Table 4).

The infection levels induced by each Calonectria spp. were always significantly higher in Callistemon Captain Cook than in M. excelsa Aurea (Table 4). The boscalid + pyraclostrobin mixture provided the best performance in controlling Calonectria leaf spot, except for those caused by $C$. mexicana (Table 4), in which significant differences were not detected for SS. Similarly, the cyprodinil + fludioxonil mixture alone or applied in combination with both bioformulations

Table 3. Effects of fungicides and biological control agents against stem infections caused by Calonectria morganii on Dodonaea viscosa in experiment $\mathrm{II}^{\mathrm{z}}$

\begin{tabular}{|c|c|c|c|c|}
\hline \multirow[b]{2}{*}{ Treatment } & \multicolumn{2}{|c|}{ First trial } & \multicolumn{2}{|c|}{ Second trial } \\
\hline & DI & SS & DI & SS \\
\hline $\begin{array}{l}\text { (Cyprodinil + fludioxonil) + } \\
\text { Streptomyces griseoviridis } \text { K61 }\end{array}$ & $2.4 \mathrm{~g}$ & $0.02 \mathrm{e}$ & 1.2 il & $0.01 \mathrm{~cd}$ \\
\hline Cyprodinil + fludioxonil & $6 \mathrm{fg}$ & $0.04 \mathrm{e}$ & $3.6 \mathrm{ghi}$ & $0.02 \mathrm{~cd}$ \\
\hline $\begin{array}{l}\text { (Cyprodinil }+ \text { fludioxonil) }+ \\
\text { Trichoderma atroviride } \mathrm{T} 11+ \\
\text { T. asperellum } \mathrm{T} 25\end{array}$ & $6 \mathrm{fg}$ & $0.05 \mathrm{e}$ & 01 & $0 \mathrm{~d}$ \\
\hline $\begin{array}{l}\text { (Cyprodinil + fludioxonil) + } \\
\text { T. harzianum T22 }\end{array}$ & $6 \mathrm{fg}$ & $0.06 \mathrm{e}$ & $2.4 \mathrm{hi}$ & $0.03 \mathrm{~cd}$ \\
\hline $\begin{array}{l}\text { (Cyprodinil + fludioxonil) + } \\
\text { Bacillus amyloliquefaciens } \\
\text { subsp. plantarum D747 }\end{array}$ & $8.3 \mathrm{efg}$ & $0.06 \mathrm{de}$ & $3.6 \mathrm{ghi}$ & $0.03 \mathrm{~cd}$ \\
\hline $\begin{array}{l}\text { (Cyprodinil + fludioxonil) }+ \\
\text { B. subtilis QST713 }\end{array}$ & 8.3 efg & $0.06 \mathrm{de}$ & 4.8 fghi & $0.05 \mathrm{~cd}$ \\
\hline Thiophanate-methyl & $10.7 \mathrm{ef}$ & $0.07 \mathrm{de}$ & $2.4 \mathrm{hi}$ & $0.03 \mathrm{~cd}$ \\
\hline Boscalid + pyraclostrobin & $13.1 \mathrm{e}$ & $0.09 \mathrm{de}$ & 4.8 fghi & $0.06 \mathrm{~cd}$ \\
\hline Fludioxonil & $14.3 \mathrm{de}$ & $0.11 \mathrm{de}$ & 6 efgh & $0.06 \mathrm{~cd}$ \\
\hline B. subtilis QST713 & $20.6 \mathrm{~cd}$ & $0.21 \mathrm{~cd}$ & 9.5 cdefg & $0.09 \mathrm{~cd}$ \\
\hline Fosetyl-Al & $24.1 \mathrm{c}$ & $0.31 \mathrm{c}$ & $20.2 \mathrm{c}$ & $0.17 \mathrm{c}$ \\
\hline $\begin{array}{l}\text { B. amyloliquefaciens subsp. } \\
\text { plantarum D747 }\end{array}$ & $23.8 \mathrm{c}$ & $0.3 \mathrm{c}$ & $17.9 \mathrm{~cd}$ & $0.15 \mathrm{~cd}$ \\
\hline S. griseoviridis $\mathrm{K} 61$ & $24.1 \mathrm{c}$ & $0.34 \mathrm{c}$ & 8.3 defgh & $0.08 \mathrm{~cd}$ \\
\hline $\begin{array}{l}\text { T. atroviride } \mathrm{T} 11+T \text {. asperellum } \\
\text { T25 }\end{array}$ & $29.8 \mathrm{c}$ & $0.35 \mathrm{c}$ & 10.7 cdef & $0.11 \mathrm{~cd}$ \\
\hline T. harzianum T22 & $36.9 \mathrm{~b}$ & $0.37 \mathrm{c}$ & $13.1 \mathrm{cde}$ & $0.12 \mathrm{~cd}$ \\
\hline Etridiazole & $39.3 \mathrm{~b}$ & $0.6 \mathrm{~b}$ & $27.4 \mathrm{~b}$ & $0.3 \mathrm{~b}$ \\
\hline Untreated & $81.0 \mathrm{a}$ & $1.26 \mathrm{a}$ & $53.6 \mathrm{a}$ & $0.81 \mathrm{a}$ \\
\hline
\end{tabular}

${ }^{\mathrm{z}}$ Data are the means of three replicates, each containing 28 Dodonaea seedlings. Values followed by the same letters within a column are not significantly different according to the Newman-Keuls test $(\alpha=0.05)$ for disease incidence (\%; DI) and symptom severity (centimeters; SS). Arcsine square root transformation was applied on percentage values prior to data analysis. containing Bacillus spp. significantly reduced Calonectria sp. infections, although with slight differences among the species examined (Table 4).

However, the biological treatments, on average, showed lower performances against Calonectria leaf spot. The lowest efficacy was detected for the bioformulation containing $T$. atroviride $\mathrm{T} 11+T$. asperellum $\mathrm{T} 25$, followed by those containing Bacillus spp. For the chemical treatments, fosetyl-Al provided the lowest reduction in pathogen infections (Table 4 ).

\section{Discussion}

Calonectria diseases currently represent a serious threat to ornamental plant production in the Mediterranean basin. The potential use of single applications of BCA or fungicides for controlling Calonectria diseases has been addressed in recent articles (Aiello et al. 2013; Henricot and Wedgwood 2013; LaMondia 2015; Vitale et al. 2012) but little or no information is available regarding an IPM strategy based on combinations of fungicides and microbiological formulates. Thus, our research adds useful information, contributing to a new integrated strategy using chemical and biological means against the most widespread Calonectria spp. in the Mediterranean basin (i.e., C. morganii, C. pauciramosa, C. polizzii, C. tunisiana, C. mexicana, and C. pseudomexicana).

Based on our data, the cyprodinil + fludioxonil fungicide mixture could be used in fungicide spray schedules because it provided the best performance in reducing leaf and stem infections caused by different Calonectria spp., regardless of whether they were used alone or in combination with BCA. These results were comparable with those obtained for the boscalid + pyraclostrobin fungicide mixture. For this latter formulation, Henricot and Wedgwood (2013) recently demonstrated a good efficacy against $C$. pseudonaviculata causing blight on Buxus spp. Encouraging data were also obtained for fluopyram against Calonectria leaf spot on bottlebrush. Although applications of thiophanate-methyl alone reduced Calonectria sp. infections, the use of this fungicide is discouraged because fungicide-resistant phenotypes have been detected in Italian plant nurseries (Polizzi and Vitale 2001; Vitale et al. 2009).

BCA performances were variable depending on the host, pathogen species, symptomatology, and nursery conditions involved. Indeed, microbiological formulations containing Bacillus spp., Trichoderma spp., and $S$. griseoviridis, when applied alone, were, on average, less effective than fungicides and combined treatments in reducing Calonectria sp. infections. This variability was already reported for $T$. harzianum strain T22, whose effectiveness against $C$. pauciramosa was strain specific and also dependent on the treatment's timing (Vitale et al. 2012). On the other hand, variability of disease infection levels recorded within the single experiment for the efficacy evaluation

Table 4. Effects of integrated treatments in reducing severity of leaf spot caused by five Calonectria spp. on metrosideros and bottlebrush in experiment III ${ }^{z}$

\begin{tabular}{|c|c|c|c|c|c|c|c|c|c|c|}
\hline \multirow[b]{2}{*}{ Treatment } & \multicolumn{5}{|c|}{ Metrosideros excelsa Aurea } & \multicolumn{5}{|c|}{ Callistemon Captain Cook } \\
\hline & C. $\operatorname{mex}$ & C.pau & C.pol & C.pse & C.tun & C. mex & C. pau & C. pol & C.pse & C. tun \\
\hline $\begin{array}{l}\text { (Cyprodinil + fludioxonil })+(\text { T. atroviride } \\
\mathrm{T} 11+T \text {. asperellum } \mathrm{T} 25)\end{array}$ & $1.11 \mathrm{ab}$ & $1.04 \mathrm{~b}$ & $1.04 \mathrm{~b}$ & $1.04 \mathrm{~b}$ & $1.05 \mathrm{bc}$ & $1.24 \mathrm{c}$ & $1.13 \mathrm{bc}$ & $1.07 \mathrm{~b}$ & $1.01 \mathrm{~d}$ & $1.02 \mathrm{c}$ \\
\hline $\begin{array}{l}(\text { Cyprodinil }+ \text { fludioxonil })+B \text {. } \\
\text { amyloliquefaciens subsp. plantarum D747 }\end{array}$ & $1.05 \mathrm{~b}$ & $1.06 \mathrm{~b}$ & $1.05 \mathrm{~b}$ & $1.06 \mathrm{~b}$ & $1.05 \mathrm{bc}$ & $1.06 \mathrm{c}$ & $1.03 \mathrm{c}$ & $1.04 \mathrm{~b}$ & $1.04 \mathrm{~d}$ & $1.01 \mathrm{c}$ \\
\hline $\begin{array}{l}\text { (Cyprodinil + fludioxonil) }+ \text { B. subtilis } \\
\text { QST713 }\end{array}$ & $1.05 \mathrm{~b}$ & $1.06 \mathrm{~b}$ & $1.05 \mathrm{~b}$ & $1.04 \mathrm{~b}$ & $1.05 \mathrm{bc}$ & $1.04 \mathrm{c}$ & $1.12 \mathrm{bc}$ & $1.07 \mathrm{~b}$ & $1.01 \mathrm{~d}$ & $1.01 \mathrm{c}$ \\
\hline B. amyloliquefaciens subsp. plantarum $\mathrm{D} 747$ & $1.08 \mathrm{ab}$ & $1.06 \mathrm{~b}$ & $1.05 \mathrm{~b}$ & $1.10 \mathrm{ab}$ & $1.06 \mathrm{bc}$ & $1.13 \mathrm{c}$ & $1.34 \mathrm{~b}$ & $1.29 \mathrm{~b}$ & $1.24 \mathrm{~d}$ & $1.37 \mathrm{c}$ \\
\hline B. subtilis QST713 & $1.09 \mathrm{ab}$ & $1.04 \mathrm{~b}$ & $1.03 \mathrm{~b}$ & $1.05 \mathrm{~b}$ & $1.04 \mathrm{bc}$ & $1.21 \mathrm{c}$ & $1.21 \mathrm{bc}$ & $1.32 \mathrm{~b}$ & $2.11 \mathrm{c}$ & $1.57 \mathrm{c}$ \\
\hline Boscalid + pyraclostrobin & $1.10 \mathrm{ab}$ & $1.05 \mathrm{~b}$ & $1.03 \mathrm{~b}$ & $1.03 \mathrm{~b}$ & $1.02 \mathrm{c}$ & $1.08 \mathrm{c}$ & $1.04 \mathrm{c}$ & $1.01 \mathrm{~b}$ & $1.01 \mathrm{~d}$ & $1.07 \mathrm{c}$ \\
\hline Cyprodinil + fludioxonil & $1.11 \mathrm{ab}$ & $1.02 \mathrm{~b}$ & $1.04 \mathrm{~b}$ & $1.04 \mathrm{~b}$ & $1.04 \mathrm{bc}$ & $1.16 \mathrm{c}$ & $1.13 \mathrm{bc}$ & $1.07 \mathrm{~b}$ & $1.03 \mathrm{~d}$ & $1.29 \mathrm{c}$ \\
\hline Fosetyl-Al & $1.15 \mathrm{a}$ & $1.08 \mathrm{~b}$ & $1.03 \mathrm{~b}$ & $1.06 \mathrm{~b}$ & $1.05 \mathrm{bc}$ & $1.25 \mathrm{c}$ & $1.21 \mathrm{bc}$ & $1.10 \mathrm{~b}$ & $1.39 \mathrm{~d}$ & $1.24 \mathrm{c}$ \\
\hline T. atroviride $\mathrm{T} 11+T$. asperellum $\mathrm{T} 25$ & $1.11 \mathrm{ab}$ & $1.08 \mathrm{~b}$ & $1.05 \mathrm{~b}$ & $1.05 \mathrm{~b}$ & $1.09 \mathrm{~b}$ & $1.87 \mathrm{~b}$ & $1.16 \mathrm{bc}$ & $1.22 \mathrm{~b}$ & $3.04 \mathrm{~b}$ & $2.70 \mathrm{~b}$ \\
\hline Untreated and inoculated control & $1.14 \mathrm{a}$ & $1.22 \mathrm{a}$ & $1.25 \mathrm{a}$ & $1.14 \mathrm{a}$ & $1.22 \mathrm{a}$ & $4.00 \mathrm{a}$ & $2.26 \mathrm{a}$ & $3.30 \mathrm{a}$ & $4.46 \mathrm{a}$ & $4.70 \mathrm{a}$ \\
\hline
\end{tabular}

${ }^{\mathrm{z}}$ Data are the means of three replicates, each containing 28 and 3 cuttings from metrosideros and bottlebrush, respectively. Calonectria spp.: Calonectria mexicana $=C$. mex, $C$. pauciramosa $=C$. pau, C. polizzii $=C$. pol, $C$. pseudomexicana $=C$. pse, and $C$. tunisiana $=C$. tun. Severity symptom $(\mathrm{SS})$ values followed by the same letters within a column are not significantly different according to the Newman-Keuls test $(\alpha=0.05)$. Symptom severity was calculated according to a 1-to-5 rating scale based on the percentage of infected area on the leaf surface tissues ( 0 to more than $50 \%)$. 
of integrated control means may be related to lower temperature values and humid conditions occurring in some nursery trials. It is well known that Calonectria sp. infections were most prevalent under wet, warm, and humid conditions (Crous, 2002, Vitale et al. 2013b). However, there were no significant increases in efficacy when fungicides were used in combination with BCA. Furthermore, the reduced performances of bioformulations applied alone can probably be related to the extreme inoculum density of the pathogen and environmental conditions adverse to BCA but favorable to pathogens, as was reported by Daughtrey and Benson (2005). Consequently, the BCA applications as stand-alone control measures for Calonectria disease control in nursery management cannot be largely encouraged in different agronomic and phytosanitary conditions. Based on our results, the integrated management of Calonectria sp. infections using tested chemical and biological means under our production conditions is no better than the use of chemicals alone.

Therefore, our findings do not support the adoption under actual European legislation of IPM programs to control Calonectria diseases, although this information could be useful in producing healthy ornamental plants. However, this article could be considered the starting point for the rational control of Calonectria diseases against which future IPM advances will be evaluated and compared over time. Recommendations on the decreased use of some chemical compounds, although effective against these fungi, are also reported to reduce the development of fungicide-resistant strains (FRAC 2007; Guarnaccia et al. 2014).

An effective IPM strategy can be best achieved by testing different BCA and fungicides alone or in combination, and cannot rely on a single or limited number of commercial formulations. Future studies should be oriented to the new search of BCA or integrated means to implement management of Calonectria diseases in ornamental nurseries.

\section{Acknowledgments}

This research was supported by MIUR project number PON01_01611 (SO. PRO.ME: "Sustainable production of potted plants in Mediterranean environment"). We thank V. Guarnaccia and P. T. Formica for their technical assistance in the experimental assays.

\section{Literature Cited}

Aiello, D., Cirvilleri, G., Polizzi, G., and Vitale, A. 2013. Effects of fungicide treatments for the control of epidemic and exotic Calonectria diseases in Italy. Plant Dis. 97:37-43.

Alfenas, A., Demuner, N. L., and Da Silva, A. R. 1988. Benomyl resistant strain of Cylindrocladium scoparium, causal agent of cutting rot of Eucalyptus grandis in Brazil. ISPP Chem. Control Newsl. 10:23-25.

Barnard, E. L. 1984. Occurrence, impact and fungicide control of girdling stem cankers caused by Cylindrocladium scoparium on Eucalyptus seedlings in a south Florida nursery. Plant Dis. 68:471-473.

Bertus, A. L. 1976. Cylindrocladium scoparium Morgan on Australian native plants in cultivation. Phytopathol. Z. 85:15-25.

Chase, A. R. 1987. Fungicides trials on foliage plants. Foliage Dig. 10:4-6.

Crous, P. W. 2002. Taxonomy and Pathology of Cylindrocladium (Calonectria) and Allied Genera. American Phytopathological Society, St. Paul, MN.

Daughtrey, M. L., and Benson, D. M. 2005. Principles of plant health management for ornamental plants. Annu. Rev. Phytopathol. 43:141-169.

Engelhard, A. W. 1971. Efficacy of benzimidazole dips, drenches and sprays for the control of Cylindrocladium on azalea. Plant Dis. Rep. 55:679-682.

FRAC. 2007. FRAC Code List: Fungicides Sorted by Mode of Action (including FRAC Code numbering). Online publication. Fungicide Resistance Action Committee. http://www.frac.info
Guarnaccia, V., Aiello, D., Polizzi, G., Perrone, G., Stea, G., and Vitale, A. 2014. Emergence of prochloraz-resistant populations of Calonectria pauciramosa and Calonectria polizzii in ornamental nurseries of Southern Italy. Plant Dis. 98:344-350.

Henricot, B., and Beales, P. 2003. First record of Cylindrocladium pauciramosum on myrtle (Myrtus communis) in Portugal. Plant Pathol. 52:420.

Henricot, B., Gorton, C., Denton, G., and Denton, J. 2008. Studies on the control of Cylindrocladium buxicola using fungicides and host resistance. Plant Dis. 92: 1273-1279.

Henricot, B., and Wedgwood, E. 2013. Evaluation of foliar fungicide sprays for the control of boxwood blight, caused by the fungus Cylindrocladium buxicola. Online publication. Plant Health Prog. doi:10.1094/PHP-20131024-01-RS

Hillocks, R. J. 2012. Farming with fewer pesticides: EU pesticide review and resulting challenges for UK agriculture. Crop Prot. 31:85-93.

Horst, R. K., and Hoitink, I. A. 1968. Occurrence of Cylindrocladium blights on nursery crops and control with fungicide on azalea. Plant Dis. Rep. 52:615-617.

LaMondia, J. A. 2014. Fungicide efficacy against Calonectria pseudonaviculata, causal agent of boxwood blight. Plant Dis. 98:99-102.

LaMondia, J. A. 2015. Management of Calonectria pseudonaviculata in boxwood with fungicides and less susceptible host species and varieties. Plant Dis. 99: 363-369.

Lombard, L., Crous, P. W., Wingfield, B. D., and Wingfield, M. J. 2010. Multigene phylogeny and mating tests reveal three cryptic species related to Calonectria pauciramosa. Stud. Mycol. 66:15-30.

Lombard, L., Polizzi, G., Guarnaccia, V., Vitale, A., and Crous, P. W. 2011 Calonectria spp. causing leaf spot, crown and root rot of ornamental plants in Tunisia. Persoonia 27:73-79.

Pérez-Sierra, A., Álvarez, L. A., Leòn, M., Abad-Campos, P., Henricot, B., Armengol, J., and Garcì-Jimènez, J. 2007. First report of leaf spot, blight, and stem lesions caused by Cylindrocladium pauciramosum on Callistemon in Spain. Plant Dis. 91:1057.

Polizzi, G., and Catara, V. 2001. First report of leaf spot caused by Cylindrocladium pauciramosum on Acacia retinodes, Arbutus unedo, Feijoa sellowiana and Dodonaea viscosa in Southern Italy. Plant Dis. 85:803.

Polizzi, G., and Crous, P. W. 1999. Root and collar rot of milkwort caused by Cylindrocladium pauciramosum, a new record for Europe. Eur. J. Plant Pathol. 105:407-411.

Polizzi, G., and Vitale, A. 2001. First report of the prevalence of benzimidazoleresistant isolates in a population of Cylindrocladium pauciramosum in Italy. Plant Dis. 85:1210.

Polizzi, G., Vitale, A., Aiello, D., Castello, I., Guarnaccia, I., and Parlavecchio, G. 2009. First record of crown and root rot caused by Cylindrocladium pauciramosum on brush cherry in Italy. Plant Dis. 93:547.

Polizzi, G., Vitale, A., Castello, I., Groenewald, J. Z., and Crous, P. W. 2006. Cylindrocladium leaf spot, blight, and crown rot, new diseases of mastic tree seedlings caused by Cylindrocladium scoparium. Plant Dis. 90:1110.

Roos, A. 1980. Indica Azaleas: The effect on rooting of pre-treating the mother plants and the cutting material with systemic fungicides. Verbondsnieuws Belgische Sierteelt 24:837-839.

Roos, A. 1981. Systemic fungicides and the rooting of azalea cuttings. Verbondsnieuws Belgische Sierteelt 25:433.

Vitale, A., Aiello, D., Castello, I., and Polizzi, G. 2009. First report of benzimidazoleresistant isolates of Cylindrocladium scoparium in Europe. Plant Dis. 93:110.

Vitale, A., Castello, I., D'Emilio, A., Mazzarella, R., Perrone, G., Epifani, F., and Polizzi, G. 2013a. Short-term effects of soil solarization in suppressing Calonectria microsclerotia. Plant Soil 368:603-617.

Vitale, A., Cirvilleri, G., Castello, I., Aiello, D., and Polizzi, G. 2012. Evaluation of Trichoderma harzianum strain T22 as biological control agent of Calonectria pauciramosa. BioControl 57:687-696.

Vitale, A., Crous, P. W., Lombard, L., and Polizzi, G. 2013b. Calonectria diseases on ornamental plants in Europe and the Mediterranean basin: An overview. J. Plant Pathol. 95:463-476.

Vitale, A., and Polizzi, G. 2008. First record of leaf spots and stem lesions on Pistacia lentiscus caused by Cylindrocladium pauciramosum and C. scoparium in Italy. Plant Pathol. 57:384. 